\title{
Lahars of Ruapehu Volcano, New Zealand: risk mitigation
}

\author{
Harry J.R. KEYS \\ Department of Conservation, Private Bag, Turangi 3334, New Zealand \\ E-mail: hkeys@doc.govt.nz
}

\begin{abstract}
A dam-break lahar resulting from the last eruption of Ruapehu is expected when Crater Lake reaches a critical high level, probably within the next 1-5 summers. A high level of public consultation, political decision-making and ongoing scientific input has occurred to address the risks. Decisions about managing lahar risk have taken into account the fact that lahars are common on the active Ruapehu Volcano $(2797 \mathrm{~m})$ and in valleys draining the mountain and that most lahars are generated by eruptions, about half of which have no useful precursors. Lahars threaten New Zealand's largest ski area and nationally important infrastructure. Public safety has been the main consideration but the need for long-term risk mitigation and reducing impacts on Tongariro National Park World Heritage Area have also been important. Lahar mitigation on Ruapehu now includes six lahar warning systems, each with active response plans, and some infrastructure isolated from or hardened against lahars.
\end{abstract}

\section{INTRODUCTION}

Mount Ruapehu $(2797 \mathrm{~m})$ is a glacierized composite andesite stratovolcano in the central North Island of New Zealand (Hackett and Houghton, 1989). It is the largest of three active volcanoes that make up Tongariro National Park. This is one of the oldest national parks in the world and is managed by the Department of Conservation (DOC), a New Zealand central government agency under the authority of the Minister of Conservation. The outstanding natural volcanic values of Tongariro were internationally recognized in 1990 when it was awarded World Heritage status. The area's important Maori cultural associations were accorded the same status in 1993.

The volcanic processes at Crater Lake (Figs 1,2) on Ruapehu and its immediate surroundings lie at the heart of most of these values. It is probably the most active accessible crater lake surrounded by snow and ice on Earth, and its presence facilitates valuable studies of volcanic and geothermal processes (Christenson and Wood, 1993; Hurst and Vandemeulebrouck, 1996). Small hydrothermal eruptions ('steam bursts') in the lake occur every 1-3 years: phreatic eruptions large enough to be hazardous to people occur on average every 5-10 years while larger phreatomagmatic events like the 1995-96 eruption occur every 50 years or so (Fig. 3; Houghton and others, 1987; Gillon and others, 2006). Around the volcano, lahars and other processes have developed an extensive ring plain (Donoghue and Neall, 2001). The youngest, most active portion of this plain contains a scientifically and ecologically unique sequence of lahar deposits and vegetation associations. Despite the volcanic activity, and in fact partly because of it, Ruapehu and the crater area are major areas of outdoor recreation in New Zealand. Strong management is required to protect the park's values in the face of human pressure and impact inside and outside the park's boundaries.

A dam-break lahar at Crater Lake in 1953 washed away a rail bridge at Tangiwai, $38 \mathrm{~km}$ downstream (O'Shea, 1954). Shortly afterwards a passenger train plunged into the flooded river killing 151 of the 285 passengers and crew. This was one of New Zealand's worst tragedies. Many agencies are now involved in ensuring a similar tragedy does not happen again.
This paper aims to summarize the main aspects of lahar hazards and risks on Ruapehu Volcano and provide an assessment of a predicted dam-break lahar and long-term mitigation of risks.

\section{THE LAHAR HAZARD AND RISK}

Lahars are common at Ruapehu Volcano and are usually generated by eruptions (Houghton and others, 1987; Hancox and others, 2001; Lecointre and others, 2004). At least 13 lahar episodes, with 1 to $>30$ lahars each, have occurred since 1945 (Fig. 3). Many of the lahar-generating eruptions had no useful immediate precursors such as seismicity (Latter, 1998). The most hazardous eruption in recent years was an event without precursors in April 1975 when significant lahars ran down all of the valleys draining the greater crater area (Nairn and others, 1979).

Other historic lahars have occurred weeks to years after eruptions. The 1945 eruption emptied Crater Lake and then produced a barrier of volcanic material (mainly tephra, with lava and volcanic debris) abutting glacier ice in the former lake outlet (Beck, 1950). The lake then refilled and rose above the pre-eruption level before stabilizing in the autumn of 1953. The 1953 dam-break lahar was caused by failure of the barrier in the early evening of a fine summer day, 24 December (O'Shea, 1954). The exact cause of barrier failure has never been established but presumably resulted from ongoing seepage through the barrier and erosion of it, ongoing melting of the supporting ice behind the barrier plus large meltwater flows into the lake (and possibly wave action) during the hours (or days) before the event. The released water then rapidly melted a $500 \mathrm{~m}$ long, probably subglacial path under Crater Basin Glacier and burst into the upper Whangaehu Valley. Past glacier bursts have been suspected (e.g. in February 1925) and rain events are known as other lahar triggers in historic time (Cronin and others, 1997; Hodgson and Manville, 1999; Manville, 2004).

Research has shown that there have been several lahars much larger than the 1953 and 1975 events in the last 2000 years (Cronin and others, 1997; Lecointre and others, 2004). Eruptions in 1861 and 1895 produced lahars thought 


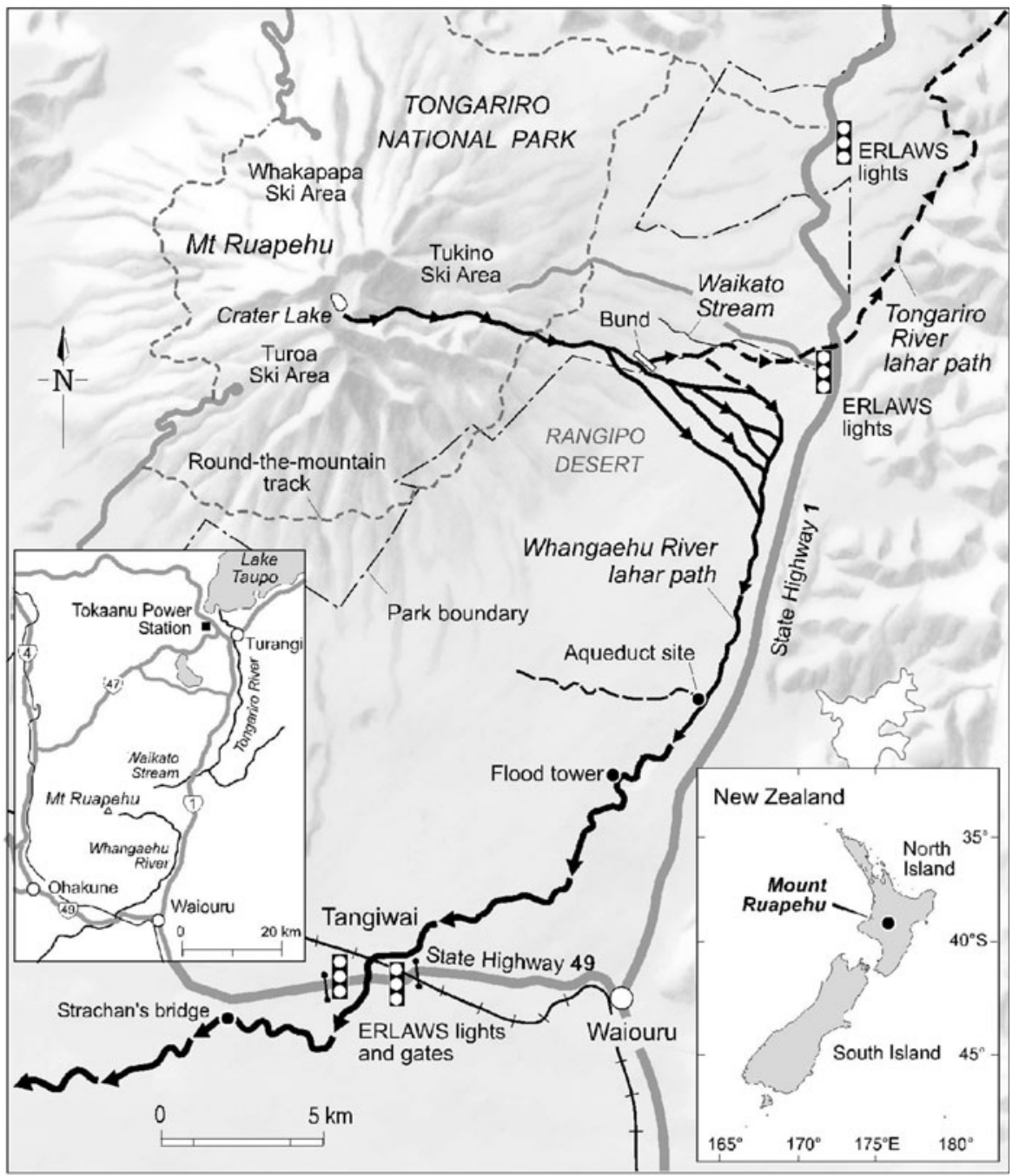

Fig. 1. Map of Ruapehu showing routes of a predicted dam-break lahar and larger lahars from rim collapse, plus major highway, rail and other infrastructure mentioned in text (see also Table 3 and Section 5).

to have had the largest volumes and/or discharges in historic time. Large prehistoric lahars are believed to have been produced by crater rim collapse, eruptions larger than any in historic time and pyroclastic interaction with snow or ice. Their average recurrence interval is about 270 years and the last such event occurred about 450 years ago. Such events would have far-reaching consequences that have been under-estimated by those who have based infrastructure design and land-use zoning on the post-1945, and the more limited post-1851, written records at Ruapehu.

Lahars pose serious risks to people using the national park and beyond, as well as some bridges and other infrastructure, especially in the Whangaehu and upper Whakapapa valleys. The Whangaehu is the major lahar path and nationally important highways, railway line, electricity transmission lines and communication systems run beside it or cross over it (Fig. 1). Two main historic lahar paths run from the crater area through Whakapapa ski area, the largest in the country, while a third path runs near a second large ski area (Turoa). Hydroelectricity facilities are vulnerable in the Whangaehu, Whakapapa and Tongariro rivers. Since 1945 the average recurrence interval of eruption lahars has been about 5 years in the Whangaehu valley and 18 years in the Whakapapa ski area (lahars in 1969, 1975 and 1995). The Tongariro valley has been subject to eruption lahars at least twice in historic time (1895 and 1975) but has also suffered from secondary lahars.

Following eruptions in 1995-96 a dam-break lahar with similarities to the 1953 event was predicted (Hancox and others, 2001). The eruptions emptied the lake, continued erosion of the crater rim and deposited $7.6 \pm 0.4 \mathrm{~m}$ of tephra on the rim at the former lake outlet. The tephra acts as a dam when the lake level rises above the slightly eroded pre-1995 outlet (the buried hard rock rim) at $2529.3 \mathrm{~m} \pm 0.3 \mathrm{~m}$. Seepage into the permeable tephra then occurs. It has been predicted that a head of water increasing above 5-6 $\mathrm{m}$ above the hard rim could lead to instability due to erosion caused by seepage emerging on the downstream face and wave erosion on the lake shore (Gillon and others, 2006) and trigger sudden collapse of the tephra dam. Whatever the rate of collapse and initial discharge rate, the majority of the lahar would travel down the normal Whangaehu lahar path, but an extreme event might be large enough to spill over into the Waikato Stream and enter the Tongariro catchment and Lake Taupo. Crater rim heights and topography (Fig. 2) mean that lahars generated by dam-break, rim collapse or glacier burst, cannot affect Whakapapa or Turoa ski areas.

The main risks to public safety from this predicted lahar arise from infrastructure being under threat. Most structures have been sited or built in the knowledge that the 


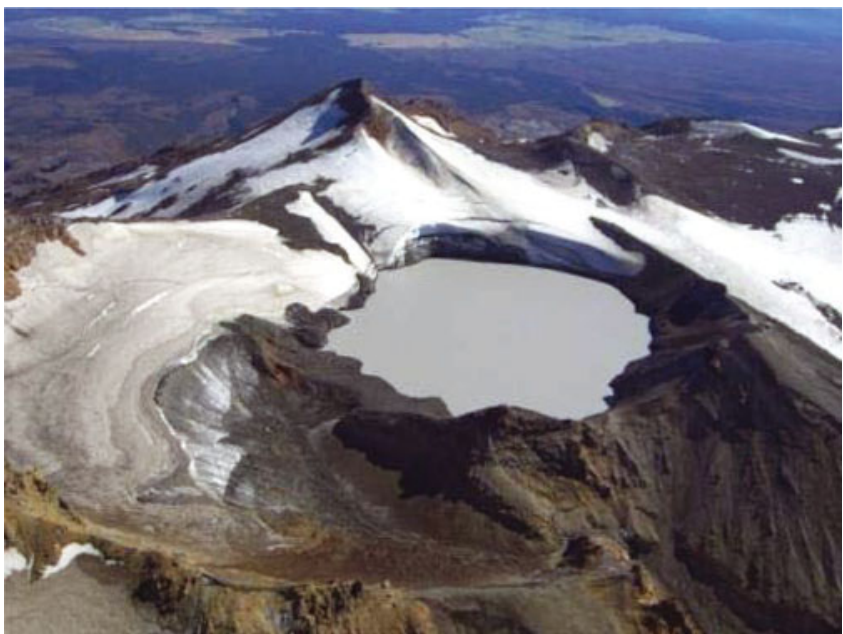

Fig. 2. Oblique aerial photo (1 April 2006) looking north over Crater Lake, with the tephra dam at the former outlet in left middle, the slowly eroding southeast rim in right middle, and the head of the Whangaehu Valley in the centre and right foreground.

Whangaehu is an active and major lahar path. There are no houses or community buildings at risk, other than a small toilet block next to a well-visited memorial to the 1953 disaster at Tangiwai. Risk mitigation is outlined below. Some $20-40 \mathrm{~km}$ below Tangiwai the lahar will become similar in size to normal rain floods (Hancox and others, 2001) and much smaller than the devastating rain floods of February 2004.

\section{CALCULATIONS OF DISCHARGE OF DAM-BREAK LAHAR}

Calculations of lahar discharge (flow rate and depth) are complex (Vignaux and Weir, 1990; Costa, 1997; Pierson, 1998; Hancox and others, 2001; Manville, 2004; Fagents and Baloga, 2005) and have been scientifically controversial at Ruapehu. Earliest estimates based on dam-break models and 1-dimensional hydraulic modelling suggested the flow at Tangiwai could be considerably larger than in 1953 (Table 1). These estimates were refined (Hancox and others, 2001; personal communication from the Science and Technical Advisory Panel, 2003) as further information became available, such as conclusions about probability of dam failure by various failure modes at specific lake levels (Gillon and others, 2006). Two sets of research since then

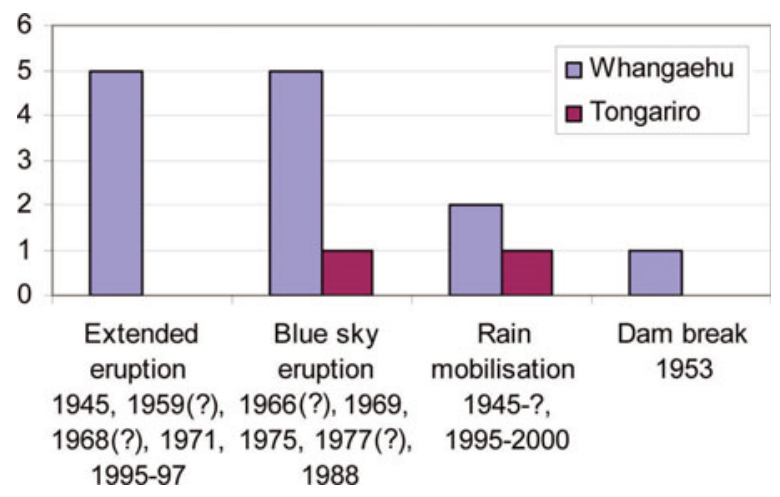

Fig. 3. The number of different types of lahar-producing episodes since 1945 (extended from Hancox and others, 2001). The number of episodes of predictable (during normal eruptions) and blue sky (unpredictable) eruption lahars are subject to similar degrees of uncertainty, due to incomplete seismic records (Latter, 1998) during earlier eruptions.

based on new modelling techniques suggest a very different lahar flow, similar in fact to the 1953 event. One uses a granular flow model and the other arises from a paleohydraulic analysis of the 1953 event (Manville, 2004).

Key points of debate and uncertainties relate to the role of glacier ice in 1953, dam-break dynamics and rates of bulking and debulking of debris entrained in the flow. Using Clarke's (2003) glacier burst model, Manville (2004) concluded that the glacier ice present in 1953 did not slowly discharge then, partly because of the warm water $\left(26^{\circ} \mathrm{C}\right)$ involved, meaning that its absence now (Fig. 2) would not lead to a greater discharge (as has been predicted by Hancox and others, 2001). Using tephra grain size, permeability data and flow modelling, Gillon and others (2006) made expert judgments on likely modes of dam failure but the duration of breach development is still poorly constrained. Estimates of lahar bulking and attenuation vary widely (Hancox and others, 2001; Manville, 2004) and have a major effect on flow estimates. Given the uncertainties, planning has focused on the worst-case scenario.

\section{ASSESSMENT}

Following the prediction of another dam-break lahar, a process to assess risk and develop mitigation measures was initiated in 1996. The Minister of Conservation is legally responsible for the management of national parks in New

Table 1. The most recent calculations and best estimates of a dam-break lahar size (flow depth and discharge) at two key points on the lahar path

\begin{tabular}{|c|c|c|c|c|}
\hline Lahar & Study & Bund area & Tangiwai rail bridge & $\begin{array}{l}\text { Maximum credible lahar } \\
\text { at Tangiwai }\end{array}$ \\
\hline $200 X^{*}$ & $\begin{array}{l}\text { Hancox, Webby and Science Panel } \\
\text { (unpublished report 2003) }\end{array}$ & $5 \mathrm{~m}$ deep, $2750 \mathrm{~m}^{3} \mathrm{~s}^{-1}$ & $6.9 \mathrm{~m}$ deep, $1200 \mathrm{~m}^{3} \mathrm{~s}^{-1}$ & $7.6 \mathrm{~m}$ deep, $1700 \mathrm{~m}^{3} \mathrm{~s}^{-1}$ \\
\hline $200 X^{*}$ & $\begin{array}{l}\text { S.J. Cronin and others (personal } \\
\text { communication, 2005) and using } \\
\text { Manville's (2004) } 1953 \text { attenuation curve }\end{array}$ & $1800-2100 \mathrm{~m}^{3} \mathrm{~s}^{-1}$ & $\begin{array}{l}500-700 \mathrm{~m}^{3} \mathrm{~s}^{-1}, \text { based on } \\
\text { discharge at bund and } \\
\text { Manville (2004) }\end{array}$ & $7.6 \mathrm{~m}$ deep, $1700 \mathrm{~m}^{3} \mathrm{~s}^{-1}$ \\
\hline
\end{tabular}

* Refers to the predicted lahar. 
Table 2. The six categories of mitigation options examined in the environmental and risk assessment

Option Objective re. lahar and methods for achieving it

category

$1 \quad$ Allow lahar to occur naturally, develop alarm and response system, improve land use planning but no engineering intervention at crater

2 Allow lahar to occur but intervene in lahar flood zones to reduce its size and/or confine it

3 Aim to prevent or reduce a lahar by hardening or perforating tephra barrier e.g. grouting, weir, tunnelling, culvert

$4 \quad$ Prevent or reduce a lahar by excavating a trench through the 1995-96 tephra barrier e.g. bulldozer, snow groomer, explosives, sluicing

$5 \quad$ Prevent a lahar and reduce lake volume by excavating trench into underlying lava at the lake outlet

Defer, prevent or reduce a lahar by other options e.g. siphoning, barrier truss

Zealand. At the Minister's request the Department of Conservation produced an environmental and risk assessment with 23 options for mitigation of the risk in six categories (Table 2). These options were developed with knowledge of work carried out at crater lakes and similar situations elsewhere around the world (e.g. Tilling, 1989), including well-known case histories at Kelud, Semeru, Ijen and other Indonesian volcanoes (e.g. Suryo and Clarke, 1985), St Helens and other US volcanoes (Childers and Carpenter, 1985), Tokachi in Japan and more recently Pinatubo in the Philippines. A draft assessment was released in October 1998, based on scientific and technical information and consultation, for agency and public comment. Other agencies then carried out their own assessments, using data and information provided by the Department of Conservation, science and engineering agencies plus their own knowledge of their assets and operating environment.

The destructive potential of lahars, highlighted by the 1953 disaster, has always targeted public and media interest. Public safety, national park/world heritage values, status and popularity, insufficient understanding of lahars and fears of impacts on jobs, businesses and the economy all focus political, management and scientific attention on the issue. This undoubtedly facilitated prioritization of agencies' budgets for research and planning. Most debate centred on whether engineering intervention was needed or desirable at the crater. A clear majority of public and agency submissions favoured options to allow the lahar to occur naturally but develop alarm and response systems and improve land-use planning.

The initial assessment with recommendations to government was carried out under a timeframe dictated by a forecast that the lake could refill by 2000 at the earliest. As it became apparent that the lake was taking longer to fill, further risk assessments of a narrowing range of risks were also prepared between 2001 and 2005 for the Ministry of Civil Defence and Emergency Management.

\section{MITIGATION OF RISKS}

Three Conservation ministers have been responsible for making a series of decisions between 1997 and March 2004 to mitigate the risks from a dam-break lahar and other potential lahars large enough to affect infrastructure on the Whangaehu and Tongariro rivers. Their decisions were made in a chronological sequence that addressed risks progressively (Table 3) in a logical way until residual risks to public safety became acceptable in the context of the overall issue. The various risk assessments were a valuable aid to the controversial interpretation of what is acceptable.

The Eastern Ruapehu Lahar Alarm and Warning System (ERLAWS) utilizes acoustic flow monitors (LaHusen, 1996) and geophones at three sites on the mountain, plus a trip wire and lake level sensors at the crater, along with repeaters necessitated by topography. Data are telemetered via dual pathways to the base at Tokaanu power station (Genesis Energy) and displayed via the internet in near real-time. When data exceed pre-set thresholds alarms are automatically sent to police and other agencies (Fig. 4). ERLAWS will also trigger automatic barrier arms at the State Highway 49 bridge plus flashing lights there and on State Highway 1 (Fig. 1). A year was required for debugging and training to achieve acceptable performance in the severe environment. Four years after commissioning, ERLAWS is proving very reliable with at least two of the three sites operating simultaneously on average $99.3 \%$ of the time.

Agencies have developed lahar plans to respond to ERLAWS. The police have the major response role with the local government agency, Ruapehu District Council, responsible for the main (southern) response plan centred on Tangiwai and the upper Whangaehu Valley, while Taupo

Table 3. Decisions by Ministers of Conservation and the government executive from 1997 to 2004, with main mitigations in bold

Month and year Decision

June 1997

Mid-late 1999

May 2000

December 2000

July 2001

October 2001

December 2001, March 2004

December 2001, May 2003, March 2004

May, December 2003
Prepare environmental and risk assessment

(Decision-making delayed by General Election)

Alarm system (ERLAWS*) and response. Independent review of Department of Conservation

Bund $^{\dagger}$ to protect public safety on State Highway 1 and Tongariro River

Establishment of Scientific and Technical Advisory Panel

Ministers Committee

Funding to Ruapehu District Council

No intervention at rim

Recommend raising and strengthening of State Highway 49 bridge

\footnotetext{
*The Eastern Ruapehu Lahar Alarm and Warning System (ERLAWS) was installed during the summer of 2001/02.

The $300 \mathrm{~m}$ long bund (sabo) structure was completed in February 2002.
} 


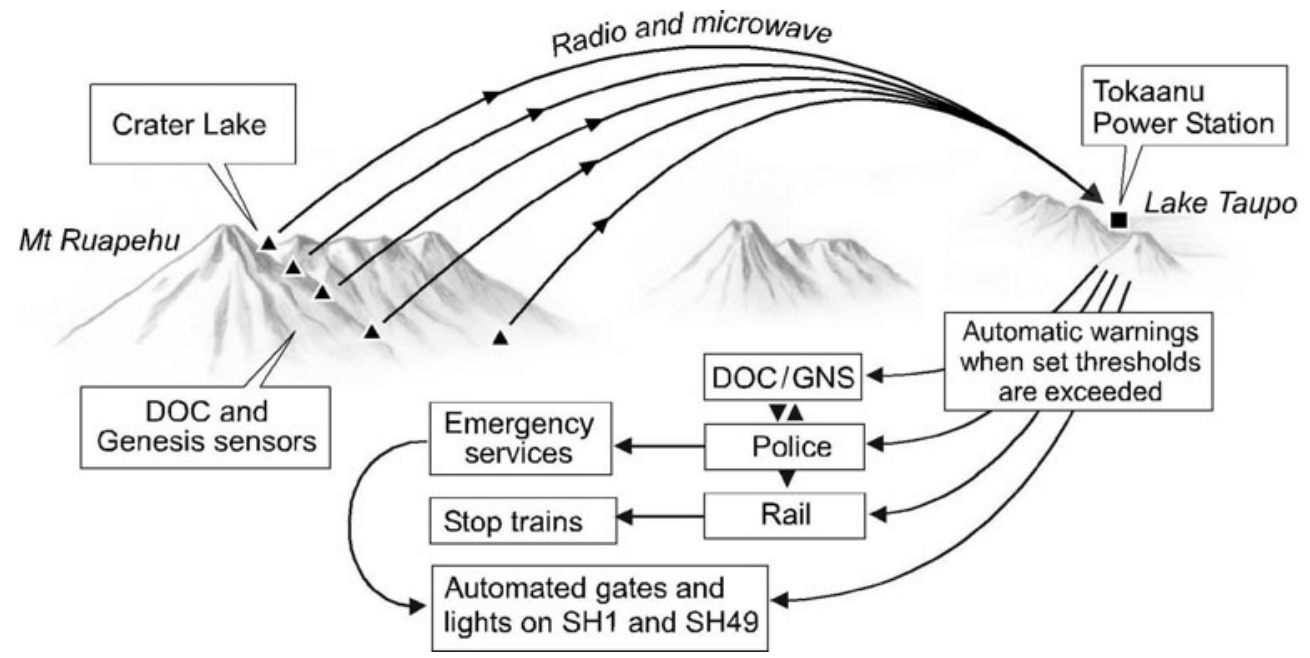

Fig. 4. Schematic of the Eastern Ruapehu Lahar Alarm and Warning System (ERLAWS).

District Council is responsible for the Tongariro River (northern) plan. The plans have been integrated, exercises and training are ongoing and interagency liaison is strong. Two melt-seasons after preparations were completed, police response is effective and within time-critical requirements. A Crater Lake warning level system has been developed as part of these plans, drawing on probabilities of dam failure at specific lake levels (Gillon and others, 2006) and predictions of lahar discharge.

The $300 \mathrm{~m}$ long bund structure is located across the uppermost northern distributary of the Whangaehu lahar outwash fan. It was constructed to prevent a distributary flow incising this part of the fan, reduce the probability that such a flow could travel $1.5 \mathrm{~km}$ downstream to the divide separating the Whangaehu and Tongariro river systems and prevent it crossing this low $1.5 \mathrm{~m}$ high divide into the Tongariro catchment. Such a crossover previously happened during a very large prehistoric lahar about 450 years ago (Lecointre and others, 2004). Prior to the bund work, the topography and lahar processes were unaltered by human activity. The bund is up to $4.2 \mathrm{~m}$ high and $20 \mathrm{~m}$ wide, and was designed to withstand a $3330 \mathrm{~m}^{3} \mathrm{~s}^{-1}$ lahar and have $1.5 \mathrm{~m}$ of freeboard above it. The maximum lahar, possibly due to the sudden collapse of the tephra dam, is about $3350 \mathrm{~m}^{3} \mathrm{~s}^{-1}$ (5.7 $\mathrm{m}$ deep) at the gorge exit $500 \mathrm{~m}$ above the bund (personal communication from the Science and Technical Advisory Panel, 2003). The probability of bund failure was estimated to be about 0.01. Recent monitoring of the river channel and lahar modelling (personal communication from S.J. Cronin and others, 2005) indicated the bund is still at design capacity and extremely unlikely to be overtopped by a predicted dam-break lahar.

Work to raise and strengthen the State Highway 49 bridge over the Whangaehu River at Tangwai (Fig. 1) was completed in January 2005. The work included constructing deeper and stronger abutments, placing steel shields around the piers, raising the bridge by $2 \mathrm{~m}$, increasing the whole structure's ability to withstand horizontal forces and raising the northern approach by $1 \mathrm{~m}$.

Other work relating to Crater Lake warning levels has either been completed to agreed timetables or is planned. A footbridge in the national park has been raised and access to the vulnerable public memorial to the 1953 disaster will be closed at warning level 2. Information is made available to the public on an ongoing basis as the lake becomes full, including signage and other warnings at vulnerable places and times. A train warning system installed above the rail bridge following the 1953 disaster had a major upgrade in 1999 and the regional government agency, Horizons Regional Council, installed an additional webcam system in 2004 as part of its emergency management procedures (http://www.horizons.govt.nz/laharcam.asp?big=true).

\section{THE QUESTION OF ENGINEERING EARTHWORKS AT THE CRATER}

Intervention at Crater Lake was ruled out in December 2001 and following reviews that decision was endorsed in May 2003 and again in March 2004 (Table 3). A fundamental question was whether interference with natural, cultural and scientific values of a World Heritage area should proceed simply because there are 'residual' risks. The risk to life is low because of the warning and response systems plus the bund, the State Highway 49 bridge work and other work, but cannot be eliminated.

Carrying out engineering work at Crater Lake would also not be without risk due to the high altitude alpine volcanic nature of the site. Such work would not prevent lahars occurring or provide long-term protection. It would also create precedents for further direct interference with other volcanic risks and other development in the National Park, and could affect management of natural hazards in the Whangaehu valley and elsewhere in New Zealand (personal communication from the New Zealand Hydrological Society, 1998). In addition, there are concerns that trying to permanently reduce the volume of Crater Lake could increase the frequency of ash eruptions (by reducing the time needed to remove the smaller lake volume and expose the vent to the atmosphere) and hence tephra falls on the ski areas: in 1995 and 1996 tephra fallout almost caused a local economic disaster when the ski companies came close to losing financial viability (personal communication from D. Mazey, Ruapehu Apine Lifts, 1997). Lowering Crater Lake might reduce the frequency or magnitude of lahars from ejection of lake water onto the ski areas but could increase the possibility of pyroclastic flows. 


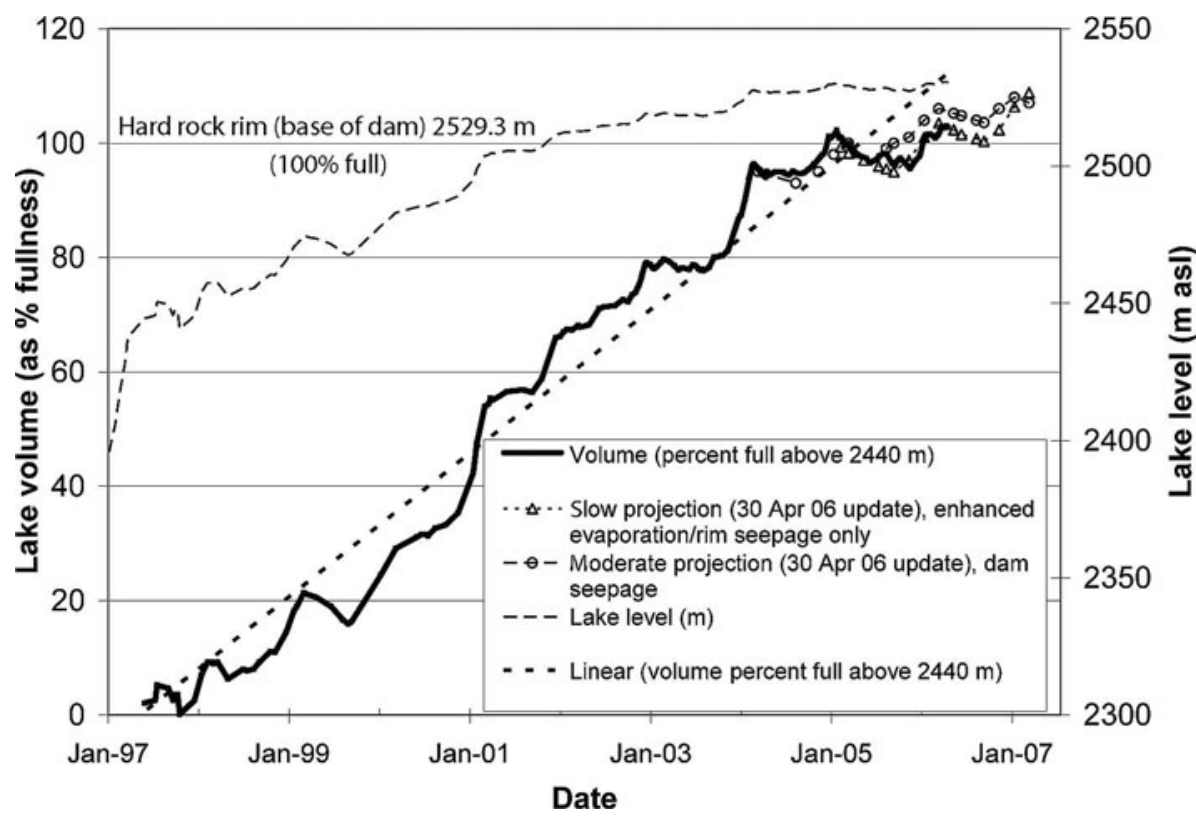

Fig. 5. Lake level and filling to September 2006, showing variations in fill rate (faster in melt season, but variable from year to year) and lake level. Projections are based on water-balance scenarios.

\section{LONG-TERM MITIGATION AND RESIDUAL RISKS}

Protecting infrastructure and other assets against future lahars is the first key to keeping people, communities and businesses resilient in the face of severe and ongoing lahar hazards. This means placing vulnerable infrastructure such as roads, rail and power lines, ski lifts and buildings at sites less likely to be at risk from lahars, isolating them from lahars or designing them in ways to withstand lahars. An increasing number of agencies operating in the area have done this. Ruapehu Alpine Lifts led the way after lahars in 1969 and 1975 caused damage on Whakapapa ski area. New and replacement buildings, lift lines and the most vulnerable lift queuing area have been located outside lahar paths and lift towers invulnerable areas strengthened to withstand lahars. Genesis Energy (and its predecessor electricity generation utilities) have been most active regarding long-term protection or survivability of assets by designing intakes well, installing remote-controlled isolating gates and procedures based on warning systems and restricting use of the Whangaehu Valley. Elsewhere, the Whangaehu Ruapehu District Council has designed and built local bridges and the Lines Company has placed bunds around power poles so they have better chances of withstanding lahars. Transit New Zealand's raising and strengthening of the State Highway 49 bridge at a cost of around NZ\$4.5 million has been the latest example.

Lahar warning and response systems are a second major tool. Ruapehu now has six systems dedicated to different volcanic risk (mostly lahar) situations, including ERLAWS and the rail and regional government webcam and response systems referred to in Section 5 on the Whangaehu lahar path. The Whakapapa Lahar Warning System was upgraded after the 1995 eruption into the Eruption Detection System (Sherburn and Bryan, 1999) and is being extended to Turoa ski area. This is designed to sound sirens and play a taped voice message through loudspeakers at vulnerable parts of Whakapapa ski area 30 seconds after volcanic earthquakes of $M \geq 3$ which are accompanied by an air wave, or all volcanic earthquakes of $M \geq 4$. The main sensors of this system are seismometers and acoustic microphones. They are also part of GeoNet, a new national earthquake and volcano monitoring system operated by the Institute of Geological and Nuclear Sciences Ltd (GNS Science). Following the upgrade, Ruapehu Alpine Lifts have improved staff training, relocated a vulnerable queue area on an upper T-bar lift and worked with the Department of Conservation and GNS Science for a public awareness campaign about volcanic hazards on the two ski areas. Genesis Energy has upgraded and extended its multi-catchment lahar detection system and is well integrated with ERLAWS. It is a challenge to maintain sensing and communication components of these systems in the crater environment.

Monitoring Crater Lake level, the tephra dam and seismic or volcanic activity remain very important for advising when critical conditions are reached or activity might be imminent. The lake rose above the level of the hard rock rim for 10 weeks in early 2005 (i.e. above $2529.3 \mathrm{~m}$, the $100 \%$ full level in Fig. 5) and has remained above that level since 27 January 2006. Various projections of filling have been made (e.g. Fig. 5) to guide deployment of resources, based on various scenarios (including seepage models referred to in Gillon and others, 2006) but are subject to much uncertainty in water balance. Inputs are difficult to quantify but are known to include meltwater from snow and glacier ice, precipitation, glacier ice calving, avalanche and snowdrift, hydrothermal fluids, thermal expansion of lake water and displacement by slumped and eroded rock material. Loss occurs mainly by evaporation, with hydrothermal drawdown, thermal contraction and seepage. Seasonal and interannual filling are highly variable so anomalies in lake water balance are difficult to detect. Statistical models of filling rate suggest that summer melt water, precipitation and evaporation provide the main controls on lake level and can explain slowing of filling or increased drawdown in recent seasons. At this time critical levels $(2535-2536 \mathrm{~m})$ seem likely to be first reached in the $2007 / 08$ summer but variability is high and a dam break 
could happen as soon as December 2006 or alternatively take another four or more summers.

An annual survey of the crater rim stability began in 1998 (Currie and Robinson, 2003) to monitor the expected radial deformation as the lake refills and seepage resumes. Annual outward movement averaged $10-15 \mathrm{~mm}$ but was up to $50 \mathrm{~mm}$ at a location where a ring-fault crack has been exposed since 1997 and was negligible in the thickest, most anchored part of the rim. The amount of annual movement tended to correlate with the annual change in lake level and appears to be reducing as the lake level stabilizes. Groundwater and stream sampling on the downstream side of the tephra dam suggest minor seepage through the dam may have commenced in late May 2006. Lake-water contribution to streams via seepage through the crater rim itself appears to be increasing as the lake level rises but is not yet enough to significantly affect lake water balance (personal communication from B. Christenson, 2006). The 1995-96 eruptions eroded the crater rim so despite the slowing in deformation, continued monitoring of rim stability remains important because increasing seepage might represent an increased possibility of rim collapse.

Better understanding and knowledge of lahars is a final requirement. Since the 1995-96 eruptions, the need and opportunity for providing better information has spurred research in New Zealand and at Ruapehu in particular. This will have national and international value regarding dambreak lahars and debris flows in general.

Despite the mitigation outlined above, there are residual risks to public safety in parts of some lahar paths. Infrastructural improvements, warning systems, increased awareness and monitoring have reduced risks from a dambreak lahar off the volcano to levels well below those estimated as achievable (personal communication from T. Taig, 2002), although they can never be eliminated. There are still vulnerable areas on the volcano, particularly on Whakapapa ski area where people have as little as two minutes following an eruption to move out of eruption lahar paths. The bund was not designed for a large lahar that might be caused by rim collapse, when it would provide only partial protection to State Highway 1. Ongoing monitoring, improvement in systems and readiness are necessary.

\section{THE FUTURE}

Tongariro National Park is the most visited national park in New Zealand. It is a place preserved for everyone - outdoor enthusiasts, conservationists, scientists, New Zealanders and tourists. Management of lahar risks at Ruapehu has local and national utility and global relevance. Major decisions on how to mitigate these risks have now largely been implemented. There are tensions between continual improvement in mitigation including refining response plans and moving on to other priorities. But the challenge and questions remain: what are appropriate levels of risk reduction and readiness for the longer term and how should they be sustained?

\section{NOTE ADDED IN PROOF}

The predicted lahar occurred on 18 March 2007. Although the lahar was a large event, no significant damage was inflicted on major infrastructure and no-one was injured. Significant community resilience has been achieved.

\section{ACKNOWLEDGEMENTS}

The support of my family, colleagues within the Department and external agencies and fellow scientists including the Science and Technical Advisory Panel is warmly acknowledged. Constructive comments from J. Gilbert, R. Blong and an anonymous reviewer improved this contribution.

\section{REFERENCES}

Beck, A.C. 1950. Volcanic activity at Mount Ruapehu from August to December 1945. New Zeal. J. Sci. Technol., B31, 1-13.

Childers, D. and P.J. Carpenter. 1985. A warning system for hazards resulting from breaches of lake blockage, Mount St Helens, Washington. In Takei, A., ed. Proceedings of International Symposium on Erosion, Debris Flow and Disaster Prevention, Tsukuba, Japan. Erosion Control Engineering Society, 493-498.

Christenson, B.W. and C.P. Wood. 1993. Evolution of a vent-hosted hydrothermal system beneath Ruapehu Crater Lake, New Zealand. Bull. Volcanol., 55(8), 547-565.

Clarke, G.K.C. 2003. Hydraulics of subglacial outburst floods: new insights from the Spring-Hutter formulation. J. Glaciol., 49(165), 299-313.

Costa, J.E. 1997. Hydraulic modeling for lahar hazards at Cascades volcanoes. Environ. Eng. Geosci., 3(1), 21-30.

Cronin, S.J., K.A. Hodgson, V.E. Neall, A.S. Palmer and J.A. Lecointre. 1997. 1995 Ruapehu lahars in relation to the late Holocene lahars of Whangaehu River, New Zealand. New Zeal. J. Geol. Geophys., 40(4), 507-520.

Currie, S. and B. Robinson. 2003. Crater lake deformation surveys at Mt Ruapehu. Surv. Quart., 35, 28-29.

Donoghue, S.L. and V.E. Neall. 2001. Late Quaternary constructional history of the southeastern Ruapehu ring plain, New Zealand. New Zeal. J. Geol. Geophys., 44(3), 439-466.

Fagents, S.A. and S.M. Baloga. 2005. Calculation of lahar transit times using digital elevation data. J. Volcan. Geotherm. Res., 139(1-2), 135-146.

Gillon, M., R. Fell, H.J.R. Keys and M. Foster. 2006. A contribution to public safety studies - failure modes and likelihood analysis for a tephra dam on an active volcano. Bulletin of ANCOLD (Australian National Committee on Large Dams), 134, 11-22.

Hackett, W.R. and B.F. Houghton. 1989. A facies model for a quaternary andesitic composite volcano: Ruapehu, New Zealand. Bull. Volcanol., 51(1), 51-68.

Hancox, G.T., H.J.R. Keys and M.G. Webby. 2001. Assessment and mitigation of dam-break lahar hazards from Mr Ruapehu Crater Lake following the 1995-96 eruptions. In Proceedings of the New Zealand Geotechnical Society Symposium - Engineering and Development in Hazardous Terrain, Christchurch 2001. Wellington, New Zealand. NZ Geotechnical Society, Institution of Professional Engineers New Zealand, 385-409.

Hodgson, K.A. and V.R. Manville. 1999. Sedimentology and flow behavior of a rain-triggered lahar, Mangatoetoenui Stream, Ruapehu volcano, New Zealand. GSA Bulletin, 111(5), 743-754.

Houghton, B.F., J.H. Latter and W.R. Hackett. 1987. Volcanic hazard assessment for Ruapehu composite volcano, Taupo Volcanic Zone, New Zealand. Bull. Volcanol., 49(6), 737-751.

Hurst, A.W. and J. Vandemeulebrouck. 1996. Acoustic noise and temperature monitoring of the Crater Lake of Mount Ruapehu Volcano. J. Volcan. Geotherm. Res., 71(1), 45-51.

LaHusen, R.G. 1996. Detecting debris flows using ground vibrations. U.S. Geological Survey Fact Sheet, 236-96.

Latter, J.H. 1998. Seismicity caused by magma intrusion, episodic degassing, and resonance in gas-filled chambers at Ruapehu Volcano, New Zealand: a record of 20 years of activity, 19711990. Sr98/29. Lower Hutt, New Zealand. Institute of Geological and Nuclear Sciences.

Lecointre, J., K. Hodgson, V. Neall and S. Cronin. 2004. Lahartriggering mechanisms and hazard at Ruapeho Volcano, New Zealand. Natur. Hazards, 31(1), 85-109. 
Manville, V. 2004. Palaeohydraulic analysis of the 1953 Tangiwai lahar: New Zealand's worst volcanic disaster. Acta Vulcanol., 16(1-2), 137-151.

Nairn, I.A., C.P. Wood and C.A.Y. Hewson. 1979. Phreatic eruptions of Ruapehu: April 1975. New Zeal. J. Geol. Geophys., 22, 155-169.

O'Shea, B.E. 1954. Ruapehu and the Tangiwai disaster. New Zeal. J. Sci. Technol., B36, 174-189.

Pierson, T.C. 1998. An empirical method for estimating travel times for wet volcanic mass flows. Bull. Volcanol., 60(2), 98-109.
Sherburn, S. and C.J. Bryan. 1999. The eruption detection system: Mt. Ruapehu, New Zealand. Seismol. Res. Let., 70 (5), 505-511.

Suryo, I. and M.G.G. Clarke. 1985. The occurrence and mitigation of volcanic hazards in Indonesia as exemplified at the Mount Merapi, Mount Kelut and Mount Galunggung volcanoes. Q.J. Eng. Geology, 18(1), 79-98.

Tilling, R.I. 1989. Volcanic hazards and their mitigation: progress and problems. Rev. Geophys., 27(2), 237-269.

Vignaux, M. and G.J. Weir. 1990. A general model for Mt. Ruapehu lahars. Bull. Volcanol., 52(5), 381-390. 